\title{
Intrafetal alcohol ablation of an acardiac twin
}

\section{Zahar Azuar Zakaria*, Roziana Ramli, Idayu Adul Malek, Maheran Abdul Razak}

Department of Obstetrics and Gynaecology, Hospital Kemaman, Malaysia

Received: 25 May 2016

Accepted: 13 June 2016

\author{
*Correspondence: \\ Dr. Zahar Azuar Zakaria, \\ E-mail: zazuarz@yahoo.co.uk
}

Copyright: (C) the author(s), publisher and licensee Medip Academy. This is an open-access article distributed under the terms of the Creative Commons Attribution Non-Commercial License, which permits unrestricted non-commercial use, distribution, and reproduction in any medium, provided the original work is properly cited.

\section{ABSTRACT}

The twin reverse arterial perfusion (TRAP) sequence is a rare but serious complication of mono-chorionic multiple pregnancies in which the affected twin is reversely perfused from the healthy co-twin. The unaffected twin is at risk of cardiac de-compensation or complication related to polyhydramnios, preterm pre-labour rupture of membrane and preterm delivery. When the risk to the healthy fetus increases significantly, the management is to occlude the circulation to the acardiac twin. Here we report a case successfully managed with intra-fetal alcohol ablation at the mid-trimester.

Keywords: TRAP, Acardiac, Intra-fetal ablation

\section{INTRODUCTION}

Acardiac malformation, also known as twin reversed arterial perfusion (TRAP) sequence, is a unique complication of mono-chorionic twinning, occurring 1 in 35000 deliveries and 1 in 100 monozygotic twins. ${ }^{1}$ The TRAP sequence involved a donor or pump twin per fusing an abnormal co-twin, usually through arterialarterial and venous-venous anastomosis. The reversal flow of the poorly oxygenated blood to the recipient twin, results in absence of cardiac structure (hence the name acardiac twin) and abnormal development of other body structures, especially in the upper part.

The condition carries a perinatal mortality of 50 to $75 \%$ to the pump twin (due to polyhydramios, preterm labour and congestive cardiac failure. ${ }^{2-4}$ The treatment options for acardiac twinning include expectant management, amniodrainage, and invasive treatment such as hysterotomy with selective delivery of the acardiac twin, intra-fetal ablation of the acardiac twin by alcohol, radiofrequency, laser or thermo-coagulation, ultrasound- guided funicular occlusion by ligation, intra-funicular embolization with foreign bodies, and fetoscopic umbilical cord occlusion by ligation, laser or thermocoagulation. $^{5-15}$

Invasive interventions have their own inherent risk and here we report successful treatment of an acardiac twin using ultrasound-guided intra-fetal ablation with alcohol in mid-trimester.

\section{CASE REPORT}

A 16 years old, para 0 , was referred to the maternal fetal Unit at 17 weeks of gestation for a suspicion of an intrauterine mass. Assessment showed a mono-chorionic, diamniotic pregnancy with a normally appearing fetus corresponding to the gestational age. The other fetus had an incompletely formed skeleton, with no head, upper limbs, heart, or thoracic structures and a dual vessels umbilical cord, typical of an acardius acephalus. The acardiac fetus was similar in size with the other fetus and no evidence of cardiac de-compensation or abnormal umbilical blood flow in the pump twin. 
She was again seen at 19 weeks of gestation and assessment showed significant increase in the acardiac fetal mass with marked subcutaneous oedema (Figure 1). Decision to intervene was made and the family was counselled about the alternatives including fetoscopic and ultrasound guided intervention. After a thorough discussion, intra-fetal chemical ablation was chosen.

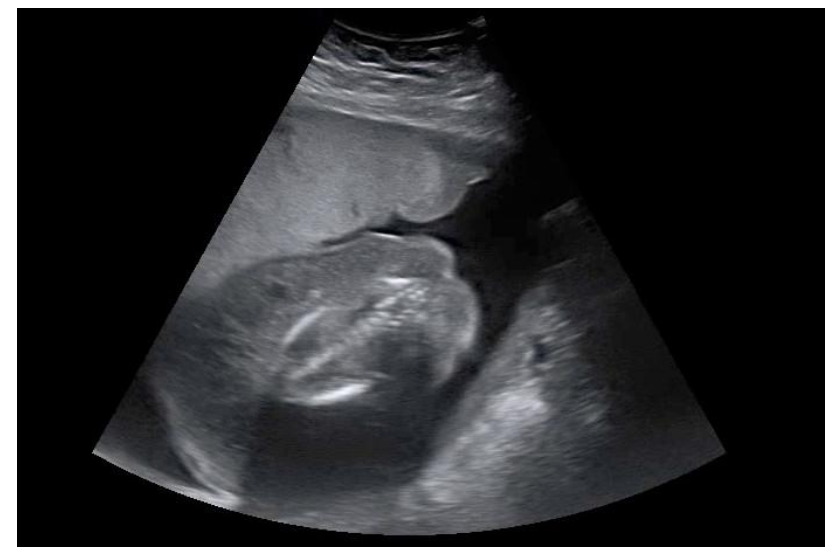

Figure 1: Oedematous acardiac fetus at 20 weeks gestation.

The procedure was performed a week later at 20 week of gestation. The intra-abdominal vessels were identified using colour flow imaging and under direct ultrasound view, a $21 \mathrm{G}$ needle was inserted into a pulsatile vessel (artery) within the acardiac twin abdomen, $0.5 \mathrm{~cm}$ from the cord attachment (Figure 2 and 3). A total of two millilitres of $95 \%$ alcohol was infused in one millilitre boluses and all intra-fetal blood flow distal to the injection site ceased almost immediately. The pump twin tolerated the procedure without any incident. Subsequent examination the day after confirmed the complete cessation of blood flow within the acardiac fetus.

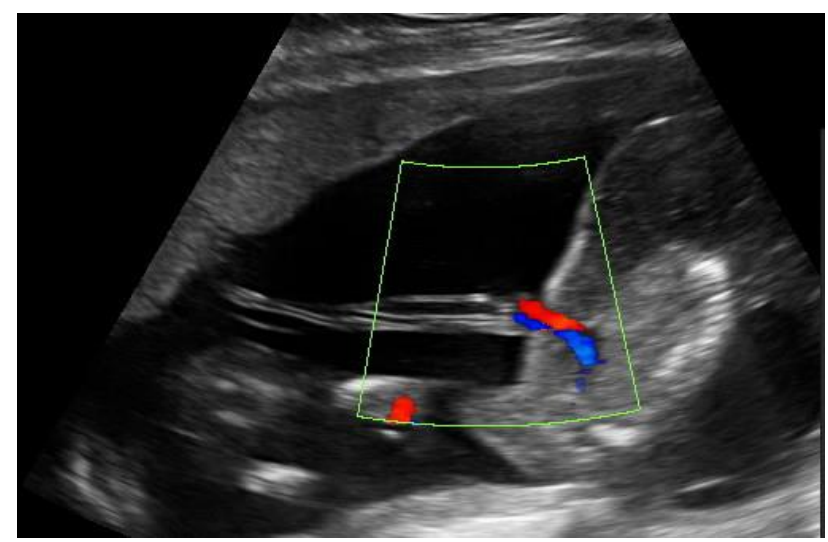

Figure 2: Intra-abdominal vessels identified using colour flow ultrasound.

The pregnancy progressed without any complication until she developed preterm pre-labour rupture of membrane at 30 weeks of gestation and was managed conservatively. However by 32 weeks the surviving fetus showed evidence of growth restriction and decision for delivery was made by 35 weeks of gestation. The delivery was achieved vaginally and a 1985 gm baby with good apgar score was delivered together with a $90 \mathrm{gm}$ acardiac fetus (Figure 4). The normal twin was allowed home after 11 days in the special care nursery.

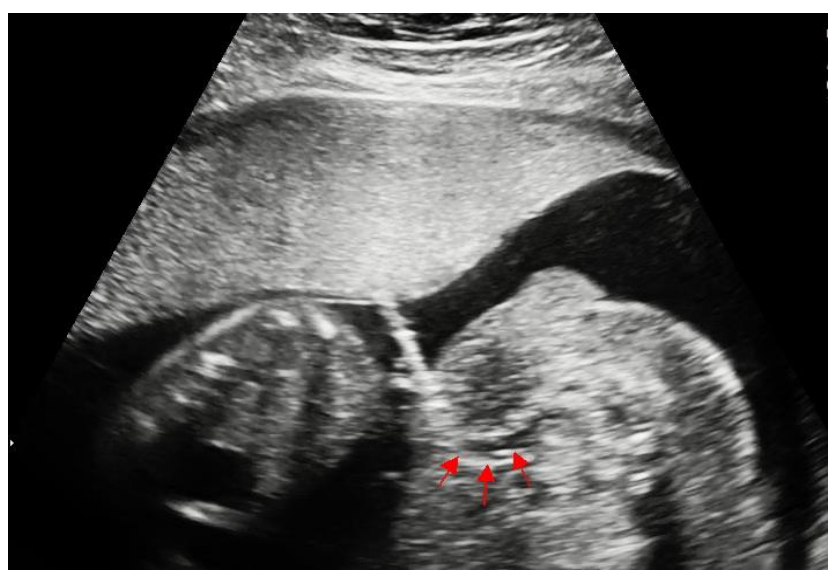

Figure 3: A needle puncturing the intra-abdominal artery (red arrows).



Figure 4: Acardiac twin at delivery. 


\section{DISCUSSION}

Being a rare mono-chorionic complication, the optimal management of TRAP, as oppose Twin to Twin Transfusion Sequence, is still unclear. The appropriate timing of intervention and the approach are still debatable.

Some authors advocated expectant management as the initial approach, and intervene when the acardiac twin show rapid growth as it had been shown to be associated with poor prognosis. ${ }^{5,17,18}$ Other prognostic factors include the twin weight ratio, umbilical doppler indices and cardiovascular status. ${ }^{19}$

Should there be the need to intervene, the main intervention is to disconnect the circulation between the two fetuses via fetoscopic or ultrasound guided occlusive techniques. Reviews on the treatment modalities suggest the intra-fetal ablation which target abdominal or pelvic vessel, easily identified regardless of the cord condition, placental location or acardiac twin position, should be offered as the first line management. ${ }^{19}$ This is due to its simpler, more effective and safer approach (compared to fetoscopic techniques). One of the more common ablative techniques is intra-fetal alcohol ablation.

Intra-fetal alcohol chemosclerosis is not without its own problem. Reported complications include death of the cotwin due to vascular thrombosis in the pump twin and failure to obliterate the target vessel despite using massive amount of alcohol. ${ }^{20,21}$

In our case, the intervention was deemed necessary when the parasitic twin grew rapidly and the procedure was completed without any complication to the mother and the normal twin. We believe, correct identification of the artery using the colour flow mode (with or without spectral doppler), careful puncture of the vessel and choosing the injection site close to the cord attachment (thereby increasing the intravascular distant from the pump twin) could reduce the risk to the normal fetus. In our case, minimal amount of sclerosing chemical was used to achieve occlusion.

Even though safer alternative technique had been developed, ultrasound guided intra-fetal ablation using laser and radiofrequency probe, chemosclerosant is still a valid option should other sophisticated methods are not available.

\section{Funding: No funding sources}

Conflict of interest: None declared

Ethical approval: Not required

\section{REFERENCES}

1. Napolitani FD, Schreiber I. The acardiac monster. A review of the world literature and presentation of 2 cases. Am J Obstet Gynecol. 1960;80:582-9.
2. Van Allen MI, Smith DW, Shepard TH. Twin reversed arterial perfusion (TRAP) sequence: a study of 14 twin pregnancies with acardius. Semin Perinatol. 1983;7:285-93.

3. Sogaard K, Skibsted L, Brocks V. Acardiac twins: pathophysiology, diagnosis, outcome, and treatment. Fetal Diagn Ther. 1999;14:53-9.

4. Quintero RA, Chmait RH, Murakoshi T, Pankrac Z, Swiatkowska M, Bornick PW, et al. Surgical management of twin reversed arterial perfusion sequence. Am J Obstet Gynecol. 2006;194(4):98291.

5. Sullivan AE, Varner MW, Ball RH, Jackson M, Silver RM. The management of acardiac twins: a conservative approach. Am J Obstet Gynecol. 2003;189:1310-3.

6. Sepulveda W, Sfeir D, Reyes M, Martinez J. Severe polyhydramnios in twin reversed arterial perfusion sequence: successful management with intra-fetal alcohol ablation of acardiac twin and amniodrainage. Ultrasound Obstet Gynecol. 2000;16(3):260-3.

7. Robie GF, Payne GG, Morgan MA. Selective delivery of an acardiac, acephalic twin. $\mathrm{N}$ Engl $\mathrm{J}$ Med. 1989;320:512-3.

8. Sepulveda A, Bower S, Hassan J, Fisk NM. Ablation of acardiac twin by alcohol injection into the intraabdominal umbilical artery. Obstet Gynecol. 1995;86:680-1.

9. Tsao K, Feldstein VA, Albanese CT, Sandberg PL, Lee H, Harrison MR, et al. Selective reduction of acardiac twin by radiofrequency ablation. Am J Obstet Gynecol. 2002;187:635-40.

10. Sepulveda W, Hasbun J, Dezerega V, Devoto JC, Alcalde JL. Successful sonographically-guided laser ablation of a large acardiac twin at 26 weeks' gestation. J Ultrasound Med. 2004;23:1663-6.

11. Rodeck C, Deans A, Jauniaux E. Thermocoagulation for the early treatment of pregnancy with an acardiac twin. N Engl J Med. 1998;339:1293-5.

12. Lemery DJ, Vanlieferingham P, Gary M, Finkeltin J, Beaufort AM. Fetal umbilical cord ligation under ultrasound guidance. Ultrasound Obstet Gynecol. 1994;4:399-401.

13. Porreco R, Barton SM, Haverkamp AD. Occlusion of umbilical artery in acardiac, acephalic twin. Lancet. 1991;337:326-7.

14. Quintero RA, Reich H, Puder KS, Bardicef M, Evans MI, Cotton DB, et al. Brief report: umbilicalcord ligation of an acardiac twin by fetoscopy at 19 weeks of gestation. N Engl J Med. 1994;330:469-71.

15. Ville Y, Hyett J, Vandenbussche FPHA, Nicolaides KH. Endoscopic laser coagulation of umbilical cord vessels in twin reversed arterial perfusion sequence. Ultrasound Obstet Gynecol. 1994;4:396-8.

16. Deprest JA, Audibert F, Van Schoubroeck D, Hecher K, Mahieu-Caputo D. Bipolar coagulation of the umbilical cord in complicated mono-chorionic twin pregnancy. Am J Obstet Gynecol. 2000;182:340-5. 
17. Wong AE, Sepulveda W. Acardiac anomaly: current issues in prenatal assessment and treatment. Prenat Diagn. 2005;25:796-806.

18. Brassard M, Fouron JC, Leduc L, Grignon A, Proulx F. Prognostic markers in twin pregnancies with an acardiac fetus. Obstet Gynecol. 1999;94:409-14.

19. Sebire NJ, Wong AE, Sepulveda W. Minimally invasive management of twin reversed arterial perfusion sequence (TRAP). Fetal and Maternal Medicine review. 2006;17:1-22.
20. Sepulveda W, Corral E, Aiello H, Otaño L, Paredes $\mathrm{R}$, Escobar MF, et al. Intra-fetal alcohol chemosclerosis of acardiac twins: a multicenter experience. Fetal Diagn Ther. 2004;19:448-52.

21. Ozenren S, Caliskan E, Corakci A, Ozkan S. Unsuccessful management of acardiac fetus with intrafetal alcohol injection. Ultrasound Obstet Gynecol. 2004;24:473-4.

Cite this article as: Zakaria AZ, Ramli R, Malek IA, Razak MA. Intrafetal alcohol ablation of an acardiac twin. Int J Reprod Contracept Obstet Gynecol 2016;5:2421-4. 